\title{
Mengatasi Persoalan Institusional Pengelolaan Sumber Daya Alam (PSDA): Pembelajaran dari Kasus Revitalisasi Ekosistem Tesso Nilo (RETN) di Provinsi Riau
}

\author{
Hariadi Kartodihardjo ${ }^{1}$ dan Chalid Muhammad ${ }^{2}$
}

\begin{abstract}
Abstrak
Penulis mengaji Revitalisasi Ekosistem Tesso Nilo (RETN) di Provinsi Riau untuk mengatasi persoalan pelanggaran penggunaan dan pemanfaatan kawasan hutan yang telah terjadi puluhan tahun lalu. Hasil identifikasi arena aksi yang terjadi selama 3 tahun terakhir menunjukkan adanya inovasi-inovasi penyelesaian masalah, keterbukaan pengambilan keputusan serta fleksibilitas tindakan sesuai dengan kondisi di lapangan. Namun prakarsa ini nampak mulai terkendala atas semakin lemahnya dukungan politik, sehingga berpotensi melonggarkan ikatan-ikatan modal sosial yang sudah mulai tumbuh di wilayah itu. Pembelajaran yang dapat diambil mencakup urgensi terhadap beberapa hal seperti pemetaan sosial untuk memprioritaskan kekuatan lokal, pentingnya membangun trust, penguasaan arena aksi, pertimbangan sejarah dan budaya untuk menghindari kecemburuan atas pilihan kelompok masyarakat dari proses administratif, orientasi pada outcome bukan hanya capaian administrasi, adanya kebutuhan pendekatan ekologi politik, skala ekosistem, maupun keterbukaan informasi.
\end{abstract}

Kata Kunci: Revitalisasi Ekosistem Tesso Nilo (RETN), Taman Nasional Tesso Nilo (TNTN), persoalan institusional, pengelolaan sumber daya alam.

\section{Abstract}

The author reviews the Revitalization of the Tesso Nilo Ecosystem (RETN) in Riau Province to address the problem of violations of the use and utilization of forest areas that have occurred decades ago. The results of the identification of the arena of action over the past 3 years show that there are innovations in problem solving, openness in decision making, and flexibility of actions in accordance with conditions in the field. But this initiative appears to be constrained due to the weakening of political support, which has the potential to loosen the bonds of social capital that have begun to grow in the region. Learning that can be taken includes the urgency of several things such as social mapping to prioritize local forces, the importance of building trust, mastery of the arena of action, historical and cultural considerations to avoid social jealousy in the choice of the community from administrative processes. the need for a political ecology approach, ecosystem scale, and information disclosure.

${ }^{1}$ Penulis adalah Ahli Kebijakan Kehutanan, Akademisi pada Institut Pertanian Bogor, dan Penasihat Senior Menteri Lingkungan Hidup dan Kehutanan 2015-2019.

${ }^{2}$ Penulis adalah Koordinator Institut Hijau Indonesia dan Penasihat Senor Menteri Lingkungan Hidup dan Kehutanan 2015-2019. 
Keywords: Revitalization of the Tesso Nilo Ecosystem (RETN), Tesso Nilo National Park (TNTN), institutional issues, natural resource management.

\section{Pendahuluan}

Dalam Pengelolaan Sumber Daya Alam (PSDA) di Indonesia, penggunaan kawasan Ekosistem Tesso Nilo (ETN) di Provinsi Riau dalam bentuk kebun sawit, menjadi fenomena salah satu bentuk kegagalan institusional di kehutanan. ETN itu terdiri atas 3 kawasan hutan dengan status konservasi Taman Nasional Tesso Nilo (TNTN) seluas 83.069 ha, kawasan hutan produksi eks HPH PT.Siak Raya Timber (SRT) seluas 38.560 ha, serta eks HPH PT.Hutani Sola Lestari (HSL) seluas 45.990 ha. Selain itu, terdapat 13 konsesi Hutan Tanaman Industri (HTI) dan 11 perusahaan kebun kelapa sawit dalam ETN. Di sekitar ETN juga terdapat 23 desa di 4 wilayah Kabupaten Kampar, Pelalawan, Indragiri Hulu dan Kuantan Singingi ${ }^{3}$.

Berdasarkan analisis tutupan lahan 2016 oleh World Wildlife Fund (WWF) Indonesia, di eks HPH PT.SRT dan eks HPH PT.HSL, hampir 90\% diindikasikan dikuasai perambah dan ditanami kelapa sawit. Begitu pula di kawasan TNTN, dari total 83.069 ha hanya sekitar 20.000 ha berupa hutan alam, sisanya diindikasikan dikuasai, dirambah dan ditanami kelapa sawit. Sementara itu, hasil identifikasi singkat pengguna lahan oleh Eyes on the Forest pada Maret 2016, pada areal eks HPH PT.SRT ditemukan 36 areal kebun yang dikuasai atau dimiliki oleh pemodal dengan luas penguasaan lebih dari 25 ha, dengan total areal 13.666 ha. Hasil yang sama juga diidentifikasi di lahan eks HPH PT.HSL. Sebanyak 64 areal kepemilikan sawit oleh pemodal dengan luas penguasaan lebih dari $25 \mathrm{ha}$, dengan total areal 15.221 ha.

Konsep kegagalan institusional telah ditafsirkan dengan berbagai perspektif. Dari perspektif ekonomi neo-klasik, didefinisikan sebagai kegagalan sektor swasta dan pemerintah ${ }^{4}$. Sementara itu, dari perspektif keberlanjutan, didefinisikan dalam hal keberlanjutan sumber daya atau ketidakmampuan untuk melestarikan sumber daya. ${ }^{5}$ Sementara itu, pendekatan inovasi membagi kegagalan institusional menjadi: (a) kegagalan institusional keras, yaitu kegagalan dalam kerangka peraturan dan sistem hukum;

\footnotetext{
3 Informasi ini diperoleh dari dokumen-dokumen pembahasan dalam penyusunan rencana pelaksanaan revitalisasi ekosistem Tesso Nilo (RETN), 2016, di Kementerian Lingkungan Hidup dan Kehutanan (KLHK).

${ }^{4}$ C. Pitelis, "Towards a Neo-classical Theory of Institutional Failure", Journal of Economic Studies. Vol 19, No.1 (1992), hlm. 14-29.

${ }^{5}$ J.M. Acheson, "Institutional Failure in Resource Management", Annual Review of Anthropology, (2006), hlm.117-134.
} 
serta (b) kegagalan kelembagaan lunak, yaitu kegagalan dalam institusi sosial seperti budaya politik dan nilai-nilai sosial. Mengikuti definisi yang berbeda-beda itu, konsep kegagalan institutional dalam naskah ini adalah terkait fungsi-fungsi lembaga negara dan regulasi maupun arena aksinya dalam pengelolaan sumber daya hutan yang cenderung gagal mewujudkan pengelolaan sumber daya hutan secara adil dan berkelanjutan. ${ }^{6}$

Dalam kerangka kerja ini, tindakan aktor-aktor yang terlibat dianggap tidak memiliki kepastian karena mereka diasumsikan bergantung, bukan hanya terhadap peraturan perundang-undangan formal (rule in form), tetapi juga terhadap kesepakatan atau tekanan yang terjadi (rule in use) pada setiap arena tindakan bersama. ${ }^{7}$ Memahami kesepakatan dan tekanan yang sedang dijalankan tersebut dapat membantu mengidentifikasi sumber-sumber kekuasaan yang digunakan dan bagaimana hal tersebut menjadi penyebab peraturan perundang-undangan dan fungsi lembaga-lembaga negara tidak berjalan. ${ }^{8}$
Naskah ini dimaksudkan untuk mendalami apakah pelaksanaan Revitalisasi Ekosistem Tesso Nilo (RETN) sebagai upaya kolaboratif Pemerintah dan masyarakat sipil, dapat mengatasi persoalan kegagalan institusional tersebut.

\section{Kerangka Pendekatan}

Secara empiris, terdapat beberapa faktor yang menyebabkan terjadinya perambahan di ETN, yaitu: ${ }^{9}$

1. kurangnya perlindungan hutan atas kawasan hutan;

2. banyaknya akses atau jalan di sekitar dan di dalam ETN sehingga memudahkan perambah masuk dan menguasai lahan;

3. aspek ekonomi yaitu meningkatnya harga tandan buah segar kelapa sawit dengan aspek pemeliharaan yang tidak terlalu rumit, serta

4. terkait aspek hukum dan kebijakan yang lemah dalam penegakannya.

Semua itu berdampak pada belum berpengaruhnya kebijakan dan komitmen pemerintah untuk menjaga hutan alam agar tetap lestari.

${ }^{6}$ R.K Woolthuis, M. Lankhuizen, \& V. Gilsing, “A system Failure Framework for Innovation Policy Design. Technovation".Techovation. Vol 25 (2005), hlm. 609-619.

7 B.D. Ratner, Ruth Meinzen-Dick, Candace May, "Resource Conflict, Collective Action, and Resilience: an Analytical Framework," International Journal of the Commons, Vol 7 (1) (February, 2013), hlm. 183-208.

${ }^{8}$ H. Kartodihardjo, Analisis Kebijakan Pengelolaan Sumberdaya Alam: Diskursus Politik Aktor Jaringan, (Bogor: Firdauss Pressindo).

${ }_{9}^{9}$ Rencana Aksi RETN 2018. Rencana Aksi RETN disusun oleh Koalisi LSM di Riau (Jikalahari, Walhi Riau, WWF, Mitra Insani, Balai Taman Nasional Tesso Nilo, Yayasan Tesso Nilo) dan digunakan oleh Tim Kerja dan Tim Operasional yang dibentuk oleh KLHK. 
Ditinjau dari implementasinya, pelaksanaan penyelesaian bentuk-bentuk pelanggaran penggunaan kawasan hutan masih belum efektif. ${ }^{10} \mathrm{Hal}$ itu disebabkan oleh faktor-faktor kompleks yang kurang memuaskan apabila dianalisis dengan pendekatan tunggal (monodisiplin). Oleh karena itu, dalam telaah pengelolaan sumber daya alam (SDA) perlu menggunakan kerangka pendekatan multi-faktor dengan model analisis dan pengembangan kelembagaan (institutional analysis development/IAD) ${ }^{11}$, untuk menilai pelaksanaan RETN. Model ini dipilih karena sangat mudah disesuaikan dengan berbagai konteks yang berbeda dan telah diterapkan pada berbagai analisis terjadinya kegagalan institusional dalam pengelolaan SDA ${ }^{12}$.

Kerangka kerja ini mempertimbangkan adanya faktor-faktor eksogenous, yaitu kondisi yang memengaruhi arena aksi tindakan para aktor, yang menentukan fungsi institusional dapat bekerja dan bagaimana menempatkan masyarakat lokal/adat sebagai subjek. Pendekatan ini memungkinkan memasukkan faktor-faktor kontekstual sesuai kondisi lapangan. Sebagai kerangka kerja yang dinamis, kinerja pada gilirannya akan memberi umpan balik ke dalam dan memengaruhi konteks serta arena tindakan berikutnya.

${ }^{10}$ Jumlah total perusahaan kelapa sawit secara nasional yang berada di dalam kawasan hutan sekitar 3,5 juta ha, dengan rincian di kawasan konservasi 115.694 ha, di hutan lindung seluas 174.910 ha, di hutan produksi terbatas seluas 454.849 ha, di hutan produksi seluas 1.484 .075 ha serta di hutan produksi yang dapat dikonversi seluas 1.244.921 ha (Auriga, 2019. Jakarta. hlm, 15). Di Riau, hasil dengar pendapat antara Komisi B DPRD Provinsi Riau dengan Kanwil Pajak Provinsi Riau-Kepri, ditemukan bahwa dari 513 perusahaan perkebunan yang terdaftar di Disbun Provinsi Riau dan 58 perusahaan kehutanan, hanya 104 perusahaan yang terdaftar sebagai penyumbang pajak di Kanwil Dirjen Pajak Riau-Kepri. Untuk tahun 2015 Kanwil Dirjen Pajak Riau-Kepri memiliki target pajak sebesar \pm Rp 24 Triliun. Kontribusi perusahaan yang bergerak dibidang P3 (Perkebunan, Perhutanan, dan Pertambangan) sekitar 40\% atau \pm Rp 9,6 Triliun. Padahal potensi pajak untuk industri perkebunan dan kehutanan yang sudah dianalisis Pansus berjumlah sekitar Rp 31,2 Triliun per tahunnya. Laporan GNPSDA KPK, 2017.

${ }^{11}$ R. J. Oakerson, Analyzing the commons: A framework. In Making the commons work (ed D.W Bromley), (San Fransisco: ICS Press, 1992), sebagaimana juga disampaikan dalam Ostrom 2005; Poteete et al. 2010.

${ }^{12}$ B.D Ratner, et al., op. cit (hlm, 186-188), yang dimodifikasi sesuai dengan kondisi lapangan ETN serta pelaksanaan revitalisasi yang telah dilakukan. 


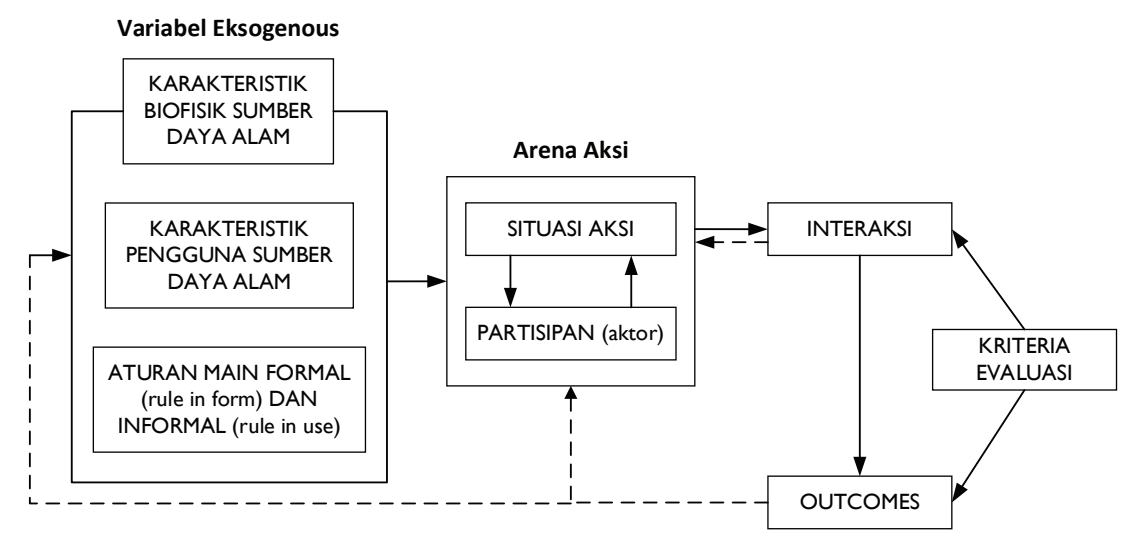

Gambar 3. Kerangka Pendekatan untuk Analisis Institutional

Faktor eksogenous pada gambar menggabungkan tiga faktor, yaitu: (a) karakteristik SDA, (b) pengguna SDA, serta (c) tata kelola termasuk "aturan khusus" yang menentukan penggunaan SDA di lapangan. ${ }^{13}$ Masing-masing faktor dapat dipecah menjadi elemen yang jauh lebih rinci tergantung pada situasi yang diteliti. ${ }^{14}$ Untuk setiap faktor, dinilai bagaimana dapat membentuk insentif bagi tindakan kolektif menuju tujuan yang ditetapkan.

Premis yang diajukan oleh Keohane dan Ostrom ${ }^{15}$ maupun Bekkers ${ }^{16}$, bah- wa dalam situasi konflik, inovasi untuk "kerja institutional baru"17 memungkinkan beragam pemangku kepentingan dapat mengelola persaingan pemanfaatan SDA secara adil, membantu membangun ketahanan, termasuk kapasitas untuk beradaptasi terhadap sumber konflik yang sedang terjadi serta risiko di masa depan. Terkait hal tersebut, terdapat konsep "kekuatan ikatan lemah" (the strength of weak ties) dalam suatu jaringan sosial. Ikatan lemah itu membuat aktor lebih mampu memperoleh informasi dari luar dibandingkan dengan aktor

${ }^{13}$ E. Ostrom, R. Gardner, \& J.M Walker, Rules, Games, and Common- Pool Resources, (Ann Arbor: University of Michigan Press, 1994), sebagaimana ditegaskan kembali dalam E. Ostrom, Understanding Institutional Diversity, (Princeton: Princeton University Press, 2005).

14 A.R Poteete, M.A. Janssen, \& E. Ostrom, Working Together: Collective Action, the Commons, and Multiple Methods in Practice, (Princeton NJ: Priceton University Press, 2010).

${ }^{15}$ R. Keohane \& E. Ostrom, Local Commons and Global Interdependence, (London: Sage, 1995).

${ }^{16}$ V. Bekkers, J. Edelenbos, \& B. Steijn, Linking Innovation to the Public Sector: Contexts, Concepts and Challenges dalam V. Bekkers, J. Edelenbos \& B. Steijn (eds), Innovation in the Public Sector: Linking Capacity and Leadership, (Houndsmills: Palgrave McMillan, 2011), hlm. 3-32.

17 Yang dimaksud yaitu menyusun perangkat kerja, regulasi, maupun konsensus bagaimana menjalankan program dan kegiatan di antara semua aktor yang terlibat. Dalam pelaksanaannya dapat mencakup inovasi proses, misalnya untuk meningkatkan kualitas dan efisiensi pelaksanaan kebijakan dengan membentuk kepemimpinan penghubung (linking leadership) yang dapat mempertemukan kepentingan kepemimpinan administratif dan kepemimpinan politik. Ibid., hlm. 24-25. 
dalam ikatan yang kuat. ${ }^{18}$ Ikatan lemah juga dapat menjembatani beragam aktor dan kelompok, menghubungkan segmen jaringan sosial yang terputus. Informasi baru cenderung mengalir melalui ikatanikatan itu. ${ }^{19}$

\section{Variabel Eksogenous}

\section{A. Karakteristik SDA dan Penggunanya}

SDA baik terbarukan atau tidak, dapat mewujudkan tekanan dan sumber konflik terutama apabila bersifat High Exclusion Cost (HEC). ${ }^{20}$ Dengan sifat itu, lebih sulit mengecualikan orang yang tidak berhak pada sumber daya yang tersebar, dibandingkan dengan yang sangat terkonsentrasi, dari ikut serta memanfaatkan. Wilayah ETN yang dikaji ini memenuhi kriteria sifat $\mathrm{HEC}^{21}$. Kondisi demikian terjadi, tidak terlepas dari perubahan-perubahan pengelolaan kawasan sejak tahun 1970-an dan pengelola yang tidak kuat. ${ }^{22}$ Sementara itu, telah diketahui bahwa semakin dapat dikuasai suatu SDA, semakin mudah membangun pengaturan institusional dalam pengelolaannya ${ }^{23}$. Sifat langka dan sifat HEC SDA di lokasi ETN secara konseptual dan empiris menyulitkan pelaksanaan pengelolaannya.

Di lokasi ETN, Balai TN Tesso Nilo dan WWF Indonesia telah melakukan identifikasi pengguna lahan selama

${ }^{18}$ W. Liu, A.M. Beacom, T.W Valente, "Social Network Theory: The International Encyclopedia of Media Effects", (2017), https://www.researchgate.net/publication/316250457_Social_Network_ Theory/link/59cca8c8a6fdcc451d61779f/download.

${ }^{19}$ C. Prell, K. Hubacek, M. Reed, "Stakeholder Analysis and Social Network Analysis in Natural Resource Management", Society \& Natural Resources: An International Journal, Vol. 22 (6), hlm. 501-518.

${ }^{20}$ Barang dengan biaya eksklusi atau pengecualian tinggi (HEC) adalah barang di mana apabila barang itu untuk satu pengguna, mahal untuk mengeluarkan pengguna lainnya agar tidak ikut memanfaatkannya. Karena biaya untuk mengeluarkan pengguna lainnya itu lebih besar dari nilai barang yang dibicarakan. Biaya pengecualian yang tinggi berarti bahwa penggunaan barang yang ada tidak dapat terbatas pada mereka yang telah berkontribusi pada biaya produksinya atau hak atas barang itu. Hanya karena seseorang memiliki hak untuk mengeluarkan orang lain dari sumberdaya itu tidak berarti bahwa upaya mengeluarkan hak orang lain dapat dilakukan secara efektif. A. Schmid, Property, Power, and an Inquiry into Law and Economy, (New York: Praeger, 1987), hlm. 43-54.

${ }^{21}$ Keseluruhan areal ETN seluas $916.343 \mathrm{Ha}$, areal TNTN di dalamnya seluas 81.793 ha, yang telah dirambah seluas 44.544 ha (54\%). Areal eks PT. HSL seluas 45.990 ha dan areal eks PT. SRT seluas 38.560 ha, yang telah dirambah seluas 55.834 ha (66\%). Disamping itu terdapat 13 perusahaan HTI dengan luas sekitar 750.000 ha, 9 perusahaan terdapat klaim lahan. Juga terdapat HGU kelapa sawit 11 perusahaan seluas 70.193 ha, diantaranya seluas 15.808 di dalam kawasan hutan. Laporan Koalisi LSM Riau, 2017.

${ }^{22}$ Pada 1974 wilayah TNTN masih menjadi konsesi HPH PT. Dwi Marta (200.000 ha) dan PT. Nanjak Makmur (48.370 ha). Pada 1993 dialihkan pengelolaan PT Dwi Marta kepada PT Inhutani IV (BUMN). Tahun 2001-2002 kawasan tersebut oleh Pemda Kabupaten dan Provinsi setuju diubah menjadi kawasan konservasi gajah dan tahun 2004 sebagian kawasan PT Inhutani IV (38.576 ha) diubah fungsinya menjadi TNTN. Tahun 2009 areal PT. Nanjak Makmur juga diubah fungsinya menjadi TNTN. Tahun 2014 kawasan TNTN ditetapkan dengan SK. KepMenHut No. 6588/Menhut-VII/KUH/2014, 28 Oktober 2014, tentang Penetapan Kawasan Hutan Taman Nasional Tesso Nilo seluas 81.793 Ha di Kabupaten Pelalawan dan Kabupaten Indragiri Hulu. Laporan Menteri KLHK, 2018.

${ }^{23}$ A. Agrawal, "Common Property Institutions and Sustainable Governance of Resources", World Development, Vol. 29, No. 10 (2001), hlm. 1649-1672. 
2016-Juni 2018. Ditemukan kepemilikan lahan 0-5 ha seluas 903 ha, 6-10 ha seluas 1.711 ha, 11-15 ha seluas 637 ha, 16-20 ha seluas 952 ha, 20-25 ha seluas 586 ha dan lahan di atas 25 ha mencapai 19.839 ha. Dari total 19.839 ha tersebut dikuasai sekitar 165 orang pemilik modal (Lihat Gambar 4)

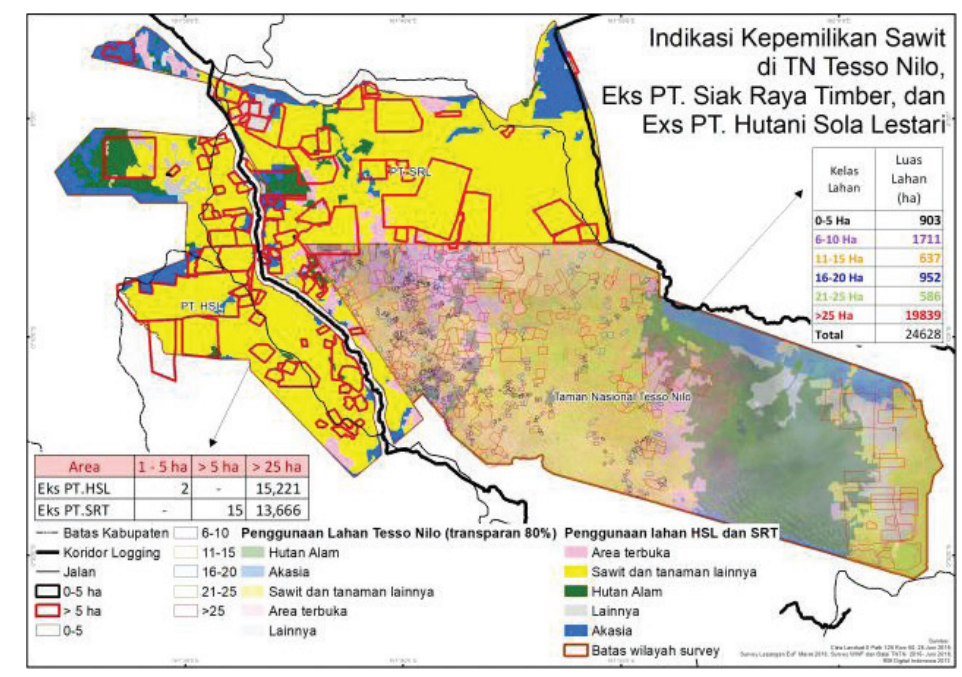

Gambar 4. Identifikasi Penguasaan Lahan di ETN (Sumber: WWF Indonesia, 2016)

Pada gambar tersebut, di wilayah Eks PT. HSL di Kecamatan Logas Tanah Datar, Kabupaten Kuantan Singingi dengan luas 9.586,37 ha, masuk dalam wilayah adiministrasi 4 desa, yaitu Situgal, Hulu Tesso, Sidodadi dan Girisako ${ }^{24}$. Wilayah ini secara de facto di bawah penguasaan Masyarakat Adat Mandailing yang berperan penting dan memiliki keterkaitan hubungan sosial dengan penguasaan lahan. Areal eks PT.HSL yang masuk dalam wilayah adat Mandailing Logas Tanah Darat meliputi 7 desa, yaitu Desa Logas, Lubuk Kebun, Situgal, Hulu Tesso, Giri Sako, Sidodadi dan Kuantan
Sako. Di wilayah ini, pembukaan areal baru dan jual beli lahan harus memperoleh izin dari pemangku adat Mandailing. Pembukaan lahan perkebunan oleh masyarakat dan cukong di wilayah ini dimulai pada tahun 2005 yang diawali dengan keluarnya izin dari tokoh pemuka adat untuk pemodal/cukong. Dengan mekanisme serupa, saat ini hampir 80\% areal eks PT.HSL telah terbuka dan dimanfaatkan untuk perkebunan kelapa sawit.

Selain karakteristik SDA atau sifat HEC tersebut, karakteristik sosial ekonomi seperti etnis, pendidikan maupun

${ }^{24}$ Diperoleh dari laporan evaluasi kegiatan revitalisasi ekosistem Tesso Nilo (RETN) yang disusun oleh LSM di Riau, yang menjadi anggota Tim Operasional RETN, 13 Maret 2017. 
kekayaan sangat menentukan potensi konflik dapat terjadi. ${ }^{25}$ Hasil penelitian tentang faktor-faktor yang memengaruhi pengelolaan sumber daya bersama juga menyatakan bahwa, kejelasan batas kelompok sebagai identitas bersama dan sejarah kerja sama lebih memungkinkan untuk mewujudkan manajemen sumber daya secara efektif. ${ }^{26}$ Namun, karakteristik pengguna SDA di ETN tidak memenuhi syarat pengelolaan sumber daya bersama seperti itu. Bahkan, dengan pengelolaan yang lemah, masyarakat menentukan sendiri kebijakan dan cara alokasi lahan untuk kebun sawit.

\section{B. Tata Kelola}

Faktor yang berkontribusi positif dalam pengelolaan SDA adalah transparansi. Karenanya, pemantauan secara independen sangat disarankan. ${ }^{27}$ Sementara itu, besar-kecilnya ukuran unit SDA maupun batas-batas yang jelas, dapat meningkatkan daya pengamatan dan mengurangi biaya pemantauan penggunaan SDA, sehingga dapat mengurangi potensi konflik. Kedua faktor itu tidak terpenuhi dalam situasi ETN.
Peraturan yang menentukan tindakan mana yang diperlukan, diizinkan atau dilarang perlu "disarangkan" ${ }^{28}$. Dalam pelaksanaan RETN, peraturan yang menjadi fokus pelaksanaannya adalah Permen KLHK No. P.83/MENLHK/ SETJEN/KUM.1/10/2016 tentang Perhutanan Sosial serta Perdirjen KSDAE No:P.6/KSDAE/SET/Kum.1/6/ 2018 tentang Petunjuk Teknis Kemitraan Konservasi pada Kawasan Suaka Alam dan Kawasan Pelestarian Alam. Dengan kondisi banyaknya pelanggaran penggunaan SDA yang telah meluas di ETN, kekuatan aksi para pihak melalui ikatanikatan yang ada, lebih besar daripada berjalannya kedua aturan tersebut. Disamping itu, sampai pertengahan 2018, Provinsi Riau belum mempunyai Peraturan Daerah mengenai penataan ruang, belum terdapat acuan penyelesaian masalah penggunaan tata ruang di tingkat provinsi.

Berdasarkan kenyataan itu, persoalan kerusakan ETN di sini dianggap berasal dari kegagalan institutional yang kemudian berkembang menjadi persoalan politik akibat kekuasaan di lapangan

\footnotetext{
${ }^{25}$ E. Ostrom, Understanding Institutional Diversity, (Princeton: Princeton University Press, 2005).

${ }^{26}$ R. Wade, Village Republics: Economic Conditions for Collective Action in South India, (Cambridge: Cambridge University Press, 1988).

${ }^{27}$ E. Ostrom, Governing the Commons, (Cambridge: Cambridge University Press, 1990).

${ }^{28}$ Yaitu tipikal untuk segenap aturan yang menentukan bagaimana segenap aturan lainnya dapat diubah. Ostrom membedakan tiga jenis aturan: (a) aturan operasional yang mengatur keputusan sehari-hari, (b) aturan pilihan kolektif yang mempengaruhi bagaimana aturan operasional harus diubah, dan siapa yang dapat mengubahnya; dan (c) aturan pilihan konstitusional digunakan dalam menyusun aturan kolektif yang pada gilirannya mengatur aturan operasional. Ibid., hlm. 50-55.
} 
melampaui apa yang dapat dilakukan oleh negara. Untuk itu, pada pertengahan 2016, sejalan dengan prioritas kerja Presiden mengenai target pelaksanaan perhutanan sosial, KLHK menjalankan RETN melalui integrasi pendekatan masyarakat, konservasi dan pengembangan wilayah. ${ }^{29}$

Dibentuk juga Tim Operasional yang secara langsung melakukan kegiatan di lapangan bersama semua Balai KLHK, Kepala TNTN, unsur Pemerintah Daerah (Pemda), Kepolisian di tingkat Provinsi dan Kabupaten, LSM, akademisi serta Lembaga Adat Melayu. Ketua Tim (Kepala Balai Besar KSDA Riau), didampingi oleh Jikalahari (sekretariat). Sebagai bentuk kepemimpinan penghubung (linking leadership), ditunjuk dua orang senior advisor Menteri KLHK.

Dalam naskah ini, respons yang bersifat institusional tersebut, dianggap sebagai kerangka penguatan institusional yang secara konseptual diperlukan, ketika hierarki otoritatif untuk menegakkan aturan, hubungan antara negara dan komunitas di lapangan tidak memadai.

\section{Arena Aksi}

Arena aksi merupakan "panggung" untuk perundingan sosial yang dapat dipilih oleh pelaku yang berbeda untuk bekerja sama atau tidak ${ }^{30}$. Dalam hal ini, penting mempertimbangkan karakteristik aktor yang terlibat, sumber daya masing-masing aktor untuk mempengaruhi orang lain, serta kendala dan peluang yang disediakan regulasi.

Di balik terjadinya deforestasi dan adanya perkebunan kelapa sawit di ETN, terdapat berbagai bentuk mekanisme transaksi. Sebagai contoh, transaksi penggunaan kawasan hutan yang dirambah dan kemudian dijadikan kebun sawit pada eks PT.HSL di Kabupaten Kuantan Singingi dapat dikategorikan menjadi 3 cara $^{31}$, yaitu: (a). Jual beli. Masyarakat lokal mendapat izin dari tokoh adat dan/atau kepala desa untuk membuka lahan di areal itu untuk perkebunan, kemudian menjualnya kepada pihak lain seperti pendatang atau pada masyarakat eks transmigrasi, (b). Hibah. Pemberian lahan oleh pemuka adat dan desa

${ }^{29}$ Hal itu sesuai dengan SK. MenLHK No. 267/Menlhk/Sekjen/HPL.4/3/2016 sebagaimana telah diubah dengan SK MenLHK No. 376/Menlhk/Sekjen/HPL.0/05/2016 mengenai RETN dan Areal Kawasan eks HPH PT.HSL dan eks HPH PT.SRT Berbasis Masyarakat.

${ }^{30}$ Gregorio, M., K. Hagedorn, M. Kirk, B. Korf, N. McCarthy, and R. Meinzen- Dick. “Property Rights, Collective Action, and Poverty: The Role of Institutions for Poverty Reduction". CAPRi Working Paper No. 81. (2008) Washington, DC: International Food Policy Research Institute.

${ }^{31}$ Penjelasan pada bagian ini, khususnya mengenai proses penggunaan areal eks HPH PT. HSL, diperoleh dengan menarasikan kembali laporan evaluasi kegiatan revitalisasi ekosistem Tesso Nilo (RETN), yang disusun oleh LSM di Riau yang menjadi anggota Tim Operasional RETN, 13 Maret 2017. 
kepada pihak lain, seperti hibah lahan di areal eks PT.HSL, ${ }^{32}$ kepada masyarakat adat Pangean seluas sekitar 2.000 ha untuk meningkatkan ekonomi anak keponakan di dua suku, (c) Kemitraan. Masyarakat yang mengklaim lahan pada eks PT.HSL bermitra dengan pemodal/ cukong untuk pembangunan kebun kelapa sawit.

Pemanfaatan lahan di lokasi tersebut adalah untuk perumahan warga lokal maupun pendatang, perkebunan kelapa sawit milik masyarakat Melayu, mantan transmigran, masyarakat pembeli dari luar yang tinggal di desa, serta perkebunan pemodal/cukong. Kebun cukong itu biasanya dengan areal lebih dari 25 ha yang kepemilikannya didominasi oleh pendatang dengan menggunakan masyarakat lokal dan luar sebagai pekerja ${ }^{33}$.

Dalam kondisi demikian, tokoh masyarakat adat/desa cukup antusias mengelola lahan bekas PT.HSL bersamasama dan bersedia ikut menertibkan kembali kepemilikan lahan yang saat itu sudah tidak dapat dikontrol oleh lembaga adat/desa. Dalam hal adanya ketidakjelasan status kepemilikan hutan/lahan, masyarakat sepakat untuk mendorong lokasi perhutanan sosial ${ }^{34}$. Namun demi- kian, disadari bahwa kemungkinan ada penolakan dari KUD Soko Jati, karena sebagain besar kebun yang berada dalam eks PT.HSL di Kuansing mengatasnamakan KUD Soko Jati yang dimiliki oleh Masyarakat Adat Pangean. Perkebunan yang dimiliki cukong/pemodal juga menjadi anggota KUD tersebut.

Strategi cukong dalam penguasaan lahan yaitu dengan memberi janji kepada masyarakat setempat atau meminta tokoh adat mengeluarkan izin pembukaan lahan untuk perkebunan sawit bagi anak/keponakan. Meskipun demikian, manajemen produksi dan perawatan kebun dilakukan sendiri dan KUD ${ }^{35}$ hanya mendapatkan fee. Untuk menyebar kepemilikan kebun illegal tersebut, sebagian kebun dikapling-kapling menjadi 2 ha atas nama masyarakat sekitar dan pendatang, terutama yang tinggal di Kecamatan Pangean dan Logas. Pekerja atau masyarakat yang berada di lokasi kebun seolah-olah menjadi pemilik kebun, padahal bukan.

Proses transaksi hutan dan tanah tersebut tidak terlepas dari penguasaan ekonomi Riau dari sektor perkebunan kelapa sawit yang mendorong penggunaan kawasan hutan/lahan secara ille-

\footnotetext{
${ }^{32}$ Sebagai wilayah adat suku Mandailing.

${ }^{33}$ Sebagian lagi didatangkan dari daerah di sekitar, Nias dan Jawa.

${ }^{34}$ Program pemerintah untuk merespons ketimpangan alokasi manfaat kawasan hutan negara. Program ini mencakup izin Hutan Kemasyarakatan, Hutan Tanaman Rakyat, Hutan Desa, Hutan Adat, serta program kemitraan.

${ }^{35}$ KUD Soko Jati.
} 
gal. ${ }^{36}$ Menghadapi situasi demikian, aktor-aktor internal terutama Pemda, yang diharapkan mengikuti sistem aturan khusus yang muncul dari perundingan institusional RETN tidak cukup merespons $^{37}$. Sementara itu, balai-balai KLHK dan jaringan LSM, cukup dapat memengaruhi proses kerja institutional yang relatif dapat mengatasi hambatan perizinan perhutanan sosial. Menghubungkan modal sosial kelompok masyarakat dengan yang berwenang untuk mempengaruhi kebijakan sangat penting untuk mengurangi konflik sosial yang lebih luas $^{38}$. Dalam pelaksanaan RETN, peran Tim Kerja dan Tim Operasional mengupayakan menghubungkan modal sosial itu, sehingga masyarakat lokal/adat dapat menempati posisi sebagai subjek, bukan sekadar objek.
Terkait upaya pengambilan keputusan yang terkendala oleh kepentingan dan kekuasaan, konsep kepemimpinan penghubung (linking leadership) cukup strategis. Intervensi itu terbukti dapat memengaruhi arena aksi dan dalam prakteknya membutuhkan sensitifitasreflektif terhadap dinamika kekuasaan. ${ }^{39}$ Sementara itu, aktor yang menjalankan fungsi jejaring sosial memastikan kebenaran subjek dan objek dalam pelaksanaan perhutanan sosial yang dicirikan oleh interkoneksi posisi maupun pengaruh. ${ }^{40}$ Dalam pelaksanaan RETN, aktor ini diisi oleh jaringan LSM di Riau, yaitu Jikalahari beserta mitra-mitranya.

Meski demikian, belum ditemukan agen perubahan dari Pemda, yang diharapkan dapat memengaruhi aktor lain menuju jalur perubahan institutional

${ }^{36}$ Dalam hasil kerja Pansus Komisi B DPRD Provinsi Riau yang diserahkan ke KPK terkait dengan pelaksanaan Gerakan Nasional Penyelamatan Sumberdaya Alam (GNPSDA) Provinsi Riau disebutkan perusahaan yang terdaftar di Dinas Perkebunan Provinsi Riau hanya 25 persen yang memiliki izin pelepasan kawasan hutan, 50 persen memiliki IUP-B atau IUP dan izin lokasi, serta 35 persen yang memiliki izin HGU. Perusahaan perkebunan kelapa sawit illegal ditengarai seluas 1.594.484 ha karena berada di dalam kawasan hutan.

${ }^{37}$ Aktor internal yang dimaksud yaitu Dinas-dinas terkait di Provinsi Riau maupun Kabupaten Pelalawan, Kampar serta Kuantan Singingi; yaitu lembaga-lembaga yang mempunyai kewenangan pengelolaan hutan dan lahan di luar kawasan konservasi. Itupun, pada sisi lainnya, perbaikan kebijakan pengelolaan sumberdaya alam telah difasilitasi melalui program GNPSDA oleh KPK. Namun pelaksanaan review izin perkebunan dan tindakan terhadap hasil review tersebut hingga pertengahan 2018 belum dijalankan.

${ }^{38}$ J. Pretty, "Social Capital and the Collective Management of Resources", Science, Vol. 302, No.5652 (2003), hlm. 1912-4.

${ }^{39}$ R. Ramirez, R. Stakeholder Analysis and Conflict Management in Cultivating Peace: Conflict and Collaboration in Natural Resource Management (ed. D. Buckles), (Ottawa: IDRC, 1999).

${ }^{40}$ Ibid., sebagaimana juga dikemukakan dalam Bodin, O. and B. I. Crona. 2009. The role of social networks in natural resource governance: What relational patterns make a difference? Global Environmental Change 19:366-374. 
permanen. Hal ini disebabkan oleh luasnya cakupan arena aksi di ETN dibandingkan aktor yang terlibat langsung, ${ }^{41}$ sehingga terdapat jual-beli lahan untuk kebun sawit serta land clearing yang dilakukan di beberapa lokasi pada saat RETN berlangsung. Untungnya kenyataan tersebut diketahui oleh Menteri KLHK, sehingga tindakan pencegahan dini pernah dapat dilakukan. ${ }^{42}$ Namun, secara umum tanggapan Pemerintah dalam menegakkan hukum dan menetapkan izin-izin perhutanan sosial masih mengalami hambatan.

Lemahnya kelembagaan formal menyebabkan tindakan yang dilakukan oleh semua aktor yang terlibat tidak konsisten sehingga bergantung pada aturan dan kesempatan yang tersedia. Hal yang cukup menguntungkan ketika dalam kasus RETN ini, Tim Operasional kebetulan dapat berkomunikasi langsung dengan Menteri KLHK maupun Direktur Jenderal terkait untuk menentukan langkah yang diperlukan.

\section{Kinerja dan Pola Kerjasama}

Apakah dalam pelaksanaan RETN masyarakat lokal/adat sebagai subjek mendapat manfaat? Apakah terdapat peningkatan fungsi institusional? ${ }^{43}$ Sejak pelaksanaan RETN tahun 2016 hingga awal 2018, Tim Kerja mendorong pelaksanaan penegakan hukum dengan berbagai pihak seperti Ditjen Penegakan Hukum KLHK, Polda Provinsi Riau, Pemprov Riau, Kabupaten Kampar, Kabupaten Pelalawan, Kabupaten Indragiri Hulu dan Kabupaten Kuantan Singingi. Telah dilakukan juga koordinasi dengan Polda Riau, khususnya terkait penanganan kasus perambahan di ETN dan terhadap perusahaan Pabrik Kepala Sawit (PKS) yang menerima sawit atau Tandan Buah Segar (TBS) dari ETN. Kapolda Riau pada 2017 telah mengeluarkan Surat Himbauan bagi PKS untuk tidak menerima dan membeli TBS dari ETN. Selain itu, itu penanganan perkara perambahan TNTN atas nama Sukhdev Singh sudah memasuki tahap persidangan dan dilakukan penangkapan alat berat di area-area perambahan eks $\mathrm{HPH}$ PT.SRT maupun TNTN.

Pada periode tersebut, Tim Operasional mengidentifikasi pengguna lahan secara partisipatif di dalam TNTN, yaitu di dalam dan sekitar Desa Bagan Limau. Dilakukan juga beberapa langkah, yaitu: (a) identifikasi target penegakan hukum

${ }^{41}$ Dalam pelaksanaan RETN ini keterlibatan swasta secara langsung sangat minimal. Swasta mengikuti proses ini hanya melalui Direktorat Jenderal Pengelolaan Hutan Lestari baik berupa sosialisasi maupun pemberitahuan agenda-agenda yang dilaksanakan.

${ }^{42}$ Terkait dengan upaya penyiapan rencana Presiden ke lokasi ETN, MenLHK pernah melakukan perjalanan ke lapangan melihat lokasi-lokasi yang akan ditetapkan sebagai program perhutanan sosial dan menemukan kasus tersebut.

${ }^{43}$ Fungsi institusional itu sendiri dalam hal ini tidak diukur unsur-unsur pembentuknya, melainkan kinerja atau outcomes yang dihasilkannya. A. Schmid, op.cit. 
terhadap pengguna lahan di TNTN; (b) sosialisasi RETN di Desa Bagan Limau, Lubuk Kembang Bunga dan Air Hitam; (c) penanaman 125 ha tanaman kehutanan dan buah-buahan; dan (d) kemitraan dengan TNTN Desa Lubuk Kembang Bunga dimana areal 12 ha dikelola oleh 5 kelompok tani di Desa Lubuk Kembang Bunga. Pembinaan daerah penyangga TN dilakukan dengan penguatan kelompok masyarakat melalui pelatihan ekonomi bisnis dan kelembagaan, pemberian bantuan usaha, maupun penyusunan master plan pemberdayaan masyarakat. Kemitraan wisata alam dengan masyarakat Desa Lubuk Kembang Bungo dihidupkan dengan mempertahankan keberadaan hutan alam tersisa melalui ekspedisi (patroli gabungan TNI dan POLRI) maupun membuat pos pengamanan di batas hutan alam yang tersisa.

Tim Operasional di eks HPH PT.SRT (didampingi Jikalahari) telah mendapat legalitas penerbitan Hutan Desa seluas 9.210 ha di Desa Pangkalan Gondai Kecamatan Langgam, Kabupaten Pelalawan. Pengajuan Hutan Desa Segati seluas 7.613 ha masih menunggu verifikasi teknis, demikian juga pengusulan Hutan Kemasyarakatan (HKm) di Desa Kesuma seluas 15.000 ha serta di Desa Sotol seluas 156,89 ha.

Tim Operasional di Eks HPH PT.HSL (didampingi Walhi Riau dan YMI) telah mendapat legalitas izin Hutan Desa Gunung Sahilan seluas 2.942 ha. ${ }^{44}$ Sedangkan pengajuan HKm di Desa Gunung Sahilan dan Sahilan Darussalam seluas 1.385 ha saat ini menunggu verifikasi teknis. Disamping itu, juga telah diajukan Hutan Desa di Desa Sidodadi seluas 7.613,12 ha yang telah diverifikasi serta pengajuan Perhutanan Sosial di Desa Situgal seluas 939 ha, Hulu Teso 790 ha dan Kuantan Sako, termasuk pemetaan wilayah untuk pengajuan PS di Desa Hulu Teso seluas 790 ha, Situgal seluas 939 ha dan Kuantan Sako.

Adanya political will Pemerintah untuk menyelesaikan akumulasi puluhan tahun persoalan ETN melalui RETN secara eksplisit baru berjalan sebatas penyelesaian-penyelesaian administrasi perizinan. Namun, secara implisit telah tumbuh modal sosial, karena semua diawali dengan pemetaan sosial termasuk penguatan hubungan antar lembaga dalam pengambilan keputusan. Namun, adanya kondisi eksternal seperti HEC, sumber daya dengan akses terbuka maupun buruknya tata kelola belum dapat dijawab melalui peningkatan kerja institusional yang dijalankan. Faktor penentu lemahnya pelaksanaan RETN pada akhirnya dapat dialamatkan pada rendahnya kapasitas kelembagaan dalam menghadapi kompleksitas arena aksi aktor-aktor yang terlibat akibat puluhan ta-

${ }^{44}$ Saat ini Rencana Kerja Hutan Desa dan Rencana Kerja Tahunan Hutan Desa Gunung Sahilan telah disahkan. 
hun penggunaan kawasan hutan secara illegal maupun keberlanjutan RETN itu sendiri.

\section{Pembelajaran}

Penelitian tentang pengelolaan sumber daya bersama sudah lama dikritik karena tidak memadai dalam memberi perhatian kepada kekuatan lokal akibat perubahan politik, sosial maupun ekonomi. ${ }^{45}$ Pendekatan RETN ini dimaksudkan untuk memprioritaskan kekuatan lokal yang diawali dengan pemetaan sosial, sekaligus memberi perspektif kepada masyarakat terkait penggunaan lahan atau hutan saat ini maupun yang akan datang. Pada saat bersamaan, kebutuhan-kebutuhan yang mereka perlukan tetap menjadi perhatian.

Prinsip utama dalam pelaksanaan RETN adalah menumbuhkan trust antara masyarakat lokal/adat dengan pengelola. ${ }^{46}$ Pemetaan sosial dilakukan juga untuk mendalami posisi setiap warga maupun hubungan-hubungan sosial yang ada, sebagai calon peserta perhutanan sosial. Hal ini dilakukan karena bertahun-tahun sebelumnya, masyarakat lokal/adat mengembangkan ekonomi dengan dasar-dasar modal illegal dengan berbagai kondisi benar-salah yang kabur. Program ini seharusnya akan mendudukkan kehadiran negara sebagaimana semestinya, dengan memulih- kan hak-hak masyarakat.

Adanya kelompok LSM yang menjalankan pemetaan sosial dan mengawal langsung kegiatan di lapangan merupakan unsur paling menentukan bagi keberhasilan program ini. Hal ini bercermin dari kondisi umum terkait perizinan bagi masyarakat local dan adat yang tidak didahului dengan pemetaan sosial. Relasi antara kepemimpinan administratif, politik maupun LSM diperlukan untuk mencapai kinerja ini.

Kedua, manfaat dari proses ini adalah adanya pengakuan interaksi berbagai aktor di berbagai tingkatan (melalui Tim Kerja dan Tim Operasional), yang mendapat persetujuan atas rencana aksi yang dijalankan, serta menguasai arena aksi di mana pilihan-pilihan tindakan para aktor dibuat dan dijalankan. Proses yang demikian. diharapkan dapat menjadi sarana pemberdayaan masyarakat melalui peningkatan potensinya guna mewujudkan kegiatan produktif, maupun mendorong terjadinya refleksi peningkatan peran lembaga-lembaga pemerintah, LSM dan juga akademisi sebagai fasilitator perubahan.

Ketiga, sejarah, budaya, atau bentuk simbolis dari sumber daya tertentu dalam prakteknya sangat penting diperhatikan sebagai instrumen menyelesaikan konflik penggunaan SDA dimana kelompok-kelompok yang bersaing saling

\footnotetext{
${ }^{45}$ A. Agrawal., op.cit.

${ }^{46}$ Pengelola kawasan konservasi dan kawasan hutan pada umumnya.
} 
memperjuangkan nilai-nilai, narasi, maupun cara membingkai masalah. Untuk itu, dalam proses administrasi perizinan seperti perhutanan sosial di lokasi ETN, seharusnya perhatian tidak hanya difokuskan kepada para calon penerima izin tetapi juga kehidupan sosial-politik masyarakat, dengan memperhatikan adanya kemungkinan kecemburuan, putusnya jaringan kerja, maupun pengembangan ekonomi pasar untuk mendukung ekonomi rumah tangga yang menjadi subjek utama. Oleh karena itu, rehabilitasi keberadaan kampung-kampung tua maupun perbaikan rumah-rumah adat juga tidak dapat dilepaskan dari program perhutanan sosial tersebut. Hal tersebut tidak dapat terlihat jika perhutanan sosial hanya dilihat dari kacamata administratif perizinan.

Keempat, pelaksanaan RETN ini dapat dilakukan atas kesadaran bahwa pelaksanaan program Pemerintah atau Pemda dan semua pihak yang terkait harus berorientasi pada hasil akhir, yaitu terwujudnya ruang hidup baru yang lebih harmonis baik bagi masyarakat lokal, adat, maupun satwa liar melalui pemulihan habitatnya. Hasil akhir itu hanya dapat diwujudkan apabila berbagai output kegiatan dari berbagai lembaga atau unit kerja dapat diintegrasikan melalui segenap pembahasan, penyele- saian masalah, peningkatan kapasitas, maupun penetapan urutan kegiatan. Kerangka kerja demikian tentu sangat berbeda dengan kerangka kerja birokrasi pemerintahan yang umumnya lebih menitikberatkan pada pertanggungjawaban administrasi. Dalam hal ini, bentuk kepemimpinan penghubung (linking leadership) menjadi kuncinya.

Kelima, diperlukan upaya mengatasi perbedaan nilai-nilai juga hubungan otoritas di antara berbagai aktor pemerintah. Oleh karena itu, kerangka kerja seperti ini seharusnya juga memasuki perspektif ekologi politik untuk melihat peran kekuasaan atau kewenangan yang dapat menafikan proses-proses yang telah berjalan serta sifat-sifat pemerintahan yang berbeda antara Pemda dan Pemerintah.

Keenam, solusi persoalan pengelolaan SDA di ETN ini membutuhkan skala ekosistem dengan kerja institutional baru yang bersarang. ${ }^{47}$ Dari pelaksanaan RETN, pendekatan ini memperhatikan keterkaitan wilayah-wilayah terutama untuk pelaksanaan revitalisasi kawasan konservasi, dengan sekaligus memperhatikan kebutuhan masyarakat atas lahan dan pemukimannya dengan memanfaatkan hutan produksi. Pendekatan ini memberi keleluasaan untuk mendapat alternatif cara penyelesaian masalah di lapangan dengan tetap memperhati-

${ }^{47}$ Sanginga, P., R. Kamugisha, and A. Martin. "The Dynamics of Social Capital and Conflict Management in Multiple Resource Regimes: A Case of the Southwestern Highlands of Uganda. Ecology and Society". Vol. 12 No.1 (2007), hlm. 6. 
kan kebutuhan perbaikan habitat maupun ruang hidup satwa liar.

Ketujuh, dalam praktek ini diperlukan keterbukaan informasi karena kepastian dan kebenaran kondisi di lapangan sangat menentukan keberhasilan suatu kegiatan dalam mencapai outcome. Hal-hal yang terkait dengan proses integrasi kegiatan maupun keterbukaan informasi, semestinya menjadi bagian dari program ini yang nantinya akan dilaksanakan sendiri oleh Pemerintah dan Pemda secara lebih utuh sesuai dengan kewenangannya.

Dengan karakteristik SDA maupun penggunanya yang khas dan menjadi perhatian dalam proses ini, apabila diperhatikan secara saksama sesungguhnya yang diperlukan adalah perbaikan kerangka kerja institutional dalam pengelolaan SDA. Kerangka kerja institutional itu diharapkan dapat melanjutkan tindakan kolektif melalui hubungan kerja inter dan antar pemerintahan serta lembaga-lembaga non pemerintah. Tantangan utama yang saat ini dihadapi yaitu keberlanjutan program itu dari pengaruh dinamika politik nasional dan daerah yang sedang terjadi, karena kerjakerja ini masih jauh dari selesai. 


\section{DAFTAR PUSTAKA}

\section{Buku}

Kartodihardjo, H. Analisis Kebijakan Pengelolaan Sumberdaya Alam: Diskursus-Politik-Aktor-Jaringan. Bogor: Firdauss Pressindo. 2017.

Keohane, R. and E. Ostrom. Local Commons and Global Interdependence. London: Sage. 1995

Oakerson, R. J. Analyzing the commons: A framework. In Making the commons work, ed. D. W. Bromley. San Francisco: ICS Press. 1992.

Ostrom, E. Governing the Commons. Cambridge: Cambridge University Press. 1990.

. Polycentricity, complexity, and the commons. The Good Society 9(2):37-41. 1999.

\section{Understanding Institutional}

Diversity. Princeton: Princeton University. 2005Press.

Ostrom, E., R. Gardner, and J. M. Walker. Rules, Games, and Common- Pool Resources. Ann Arbor, MI: University of Michigan Press. 1994.

Poteete, A. R., M. A. Janssen and E. Ostrom. Working Together: Collective Action, the Commons, and Multiple Methods in Practice. Princeton, NJ: Princeton University Press. 2010.

Schmid, A. Property, Power, and An Inquiry into Law and Economy. New York: Praeger. 1987

Wade, R. Village Republics: Economic Conditions for Collective Action in South In- dia. Cambridge: Cambridge University Press. 1988

\section{Artikel Jurnal/Media Massa}

Acheson, J.M. Institutional Failure in Resource Management. Annual Review of Anthropology, 35, 2006.

Agrawal, A. Common property institutions and sustainable governance of resources. World Development 29 (10), 2001.

Bekkers, V., J. Edelenbos \& B. Steijn, Linking Innovation to the Public Sector: Contexts, Concepts and Challenges, in: Bekkers, V., J. Edelenbos \& B. Steijn (eds.), Innovation in the public sector: linking capacity and leadership. Houndsmills: Palgrave McMillan. 2011

Bekkers, V.J.J.M., Tummers, L.G., Stuijfzand, B.G.; Voorberg, W. Social Innovation in the Public Sector: An integrative framework. LIPSE Working papers (no. 1), Rotterdam: Erasmus University Rotterdam. 2013.

Bodin, O. and B. I. Crona. The role of social networks in natural resource governance: What relational patterns make a difference? Global Environmental Change. 2009.

Liu W. Beacom AM, Valente TW. Social Network Theory. The International Encyclopedia of Media Effects. John Wiley \& Sons, Inc. 2007. DOI: 10. 1002/9781118783764.wbieme0092.

Pitelis, C. Towards a Neo-classical Theory of Institutional Failure. Journal of Economic Studies, 19(1), 1992. 
Prell C, Hubacek K, Reed M. Stakeholder analysis and social network analysis in natural resource management. Society \& Natural Resources: An International Journal. 22(6), 2009

Pretty, J. Social capital and the collective management of resources. Science 302(5652):1912-4. New York, NY. 2003.

Ratner, B.D, Ruth Meinzen-Dick, Candace May. Resource Conflict, Collective Action, and Resilience: an Analytical Framework. International Journal of the Commons. Vol. 7, no 1 February 2013, 2013.

Sanginga, P., R. Kamugisha, and A. Martin. The Dynamics of Social Capital and Conflict Management in Multiple Resource Regimes: A Case of the Southwestern Highlands of Uganda. Ecology and Society 12(1), 2007.

Woolthuis, R.K., Lankhuizen, M. \& Gilsing, V. A system failure framework for innovation policy design. Technovation, 25. 2005.

\section{Lain-lain}

AURIGA. Tipologi Penguasaan Lahan Perkebunan Sawit di dalam Kawasan Hutan dan Strategi Penyelesaiannya. Kertas Kebijakan. Jakarta. 2019

Koalisi LSM Riau, 2017. Rencana Aksi Pelaksanaan Revitalisasi Ekosistem Tesso Nilo, Propinsi Riau. Pekanbaru. 